\title{
INCLUSIONS IN DIAMONDS FROM THE K10 AND K14 KIMBERLITES, BUFFALO HILLS, ALBERTA, CANADA: DIAMOND GROWTH IN A PLUME?
}

\author{
Davies $\mathrm{RM}^{* 1,2}$, Griffin $\mathrm{WL}^{2,3}, \mathrm{O}^{\prime}$ Reilly $\mathrm{SY}^{2}$, McCandless $\mathrm{TE}^{4}$ \\ 1. American Museum of Natural History, New York, USA; ${ }^{2 .}$ GEMOC Macquarie University, Sydney, Australia; ${ }^{3 .}$ CSIRO \\ Exploration and Mining, North Ryde, Australia; ${ }^{4} \cdot$ Ashton Mining of Canada, Canada
}

A mineral mineral inclusion, carbon isotope, nitrogen content and nitrogen aggregation study of twenty-nine diamonds from the K10 and K14 Buffalo Hills kimberlites, Alberta, Canada has identified diamonds of the peridotitic $(48 \%)$, eclogitic $(41 \%)$, websteritic $(7 \%)$ and ultradeep (4\%) parageneses.

\section{MINERAL INCLUSIONS}

Peridotitic mineral inclusions have both lherzolitic and harzburgitic compositions consisting of olivine (Fo 90.3 to 92.9), Cr-pyrope garnet, $\mathrm{Cr}$-diopside and $\mathrm{Cr}$-spinel. $\mathrm{Cr}$ spinels are Fe-rich (mean $\mathrm{Mg \#}=58.2$ versus 66 for diamond inclusions worldwide $(n=156))$, but are similar to chromites in diamonds from Lac de Gras, Slave craton, Canada (mean Mg\# = 60; Davies et al., this volume).

Eclogitic diamonds contain inclusions of Cr-poor garnet, majorite garnet, clinopyroxene and rutile. Majorite, occurring in two diamonds, is rich in $\mathrm{Ca}$, $\mathrm{Ti}$ and $\mathrm{Na}$ (Fig. 1). Pressure estimates for majorite formation are between 11 and $13 \mathrm{GPa}$ (Irifune, 1987) corresponding to depths of about $400 \mathrm{~km}$ for a subcratonic geotherm, and thus have a transition zone origin.

Cr-diopside inclusions with lherzolitic compositions $(<1.5$ $\mathrm{wt} \% \mathrm{Cr}_{2} \mathrm{O}_{3} ; \mathrm{Mg} \#=93$ ) show a compositional continuum to clinopyroxenes with lower $\mathrm{Cr}_{2} \mathrm{O}_{3}(0.2$ to $0.5 \mathrm{wt} \%$; $\mathrm{Mg} \#$ $=74-87)$, moderate jadeite $(\leq 22 \mathrm{~mol} \% \mathrm{Jd})$ and $\mathrm{K}_{2} \mathrm{O}$ $(\leq 0.14$ wt $\%$; Fig. 2). Such inclusions share characteristics with both peridotitic and eclogitic diamond inclusions and here are classified as websteritic.

The websteritic clinopyroxenes occur in three diamonds, two of which also contain eclogitic clinopyroxene. This could suggest a compositional variation in the bulk chemistry of rocks encasing diamond through time with clinopyroxene inclusions trapped at different stages in the diamonds growth history. The most convincing evidence for this is from an eclogitic diamond containing garnet, majorite, eclogitic and websteritic clinopyroxene. One possibility is the websteritic clinopyroxene represents a Cr-Jd-rich high-pressure eclogitic phase from the transition zone. Alternatively the variable clinopyroxene compositions in the two diamonds could be a result of metasomatic processes (eg. Sobolev et al., 1998).
Ferropericlase, found in one diamond, is a phase formed under conditions of the lower mantle $(>660 \mathrm{~km})$, although its occurrence as an isolated phase could also indicate low Si activity at the time of inclusion entrapment, without implications of a high-pressure origin (Stachel et al. 1998, 2000). The inclusion has a composition typical of other

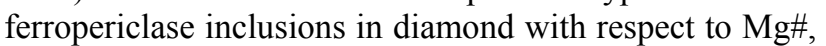
$\mathrm{Ni}$ and $\mathrm{Cr}$, and ferropericlase of similar composition has been synthesised by the high-pressure decomposition of lherzolitic olivine (e.g. Ito and Takahashi 1989).

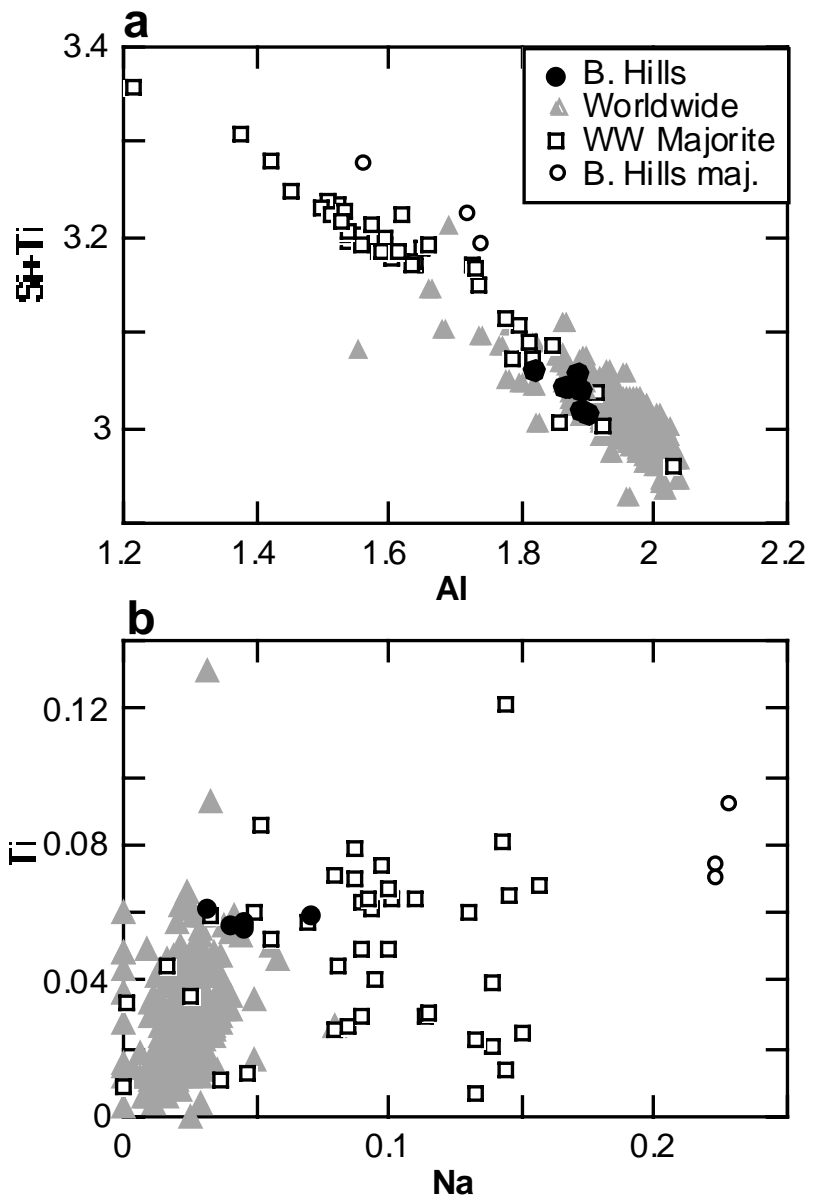

Figure 1. Compositions of eclogitic garnet and majorite in $\mathrm{K} 10$ and K14 diamonds compared to worldwide eclogitic garnet and majorite inclusions in diamond (in cations per formula unit). 

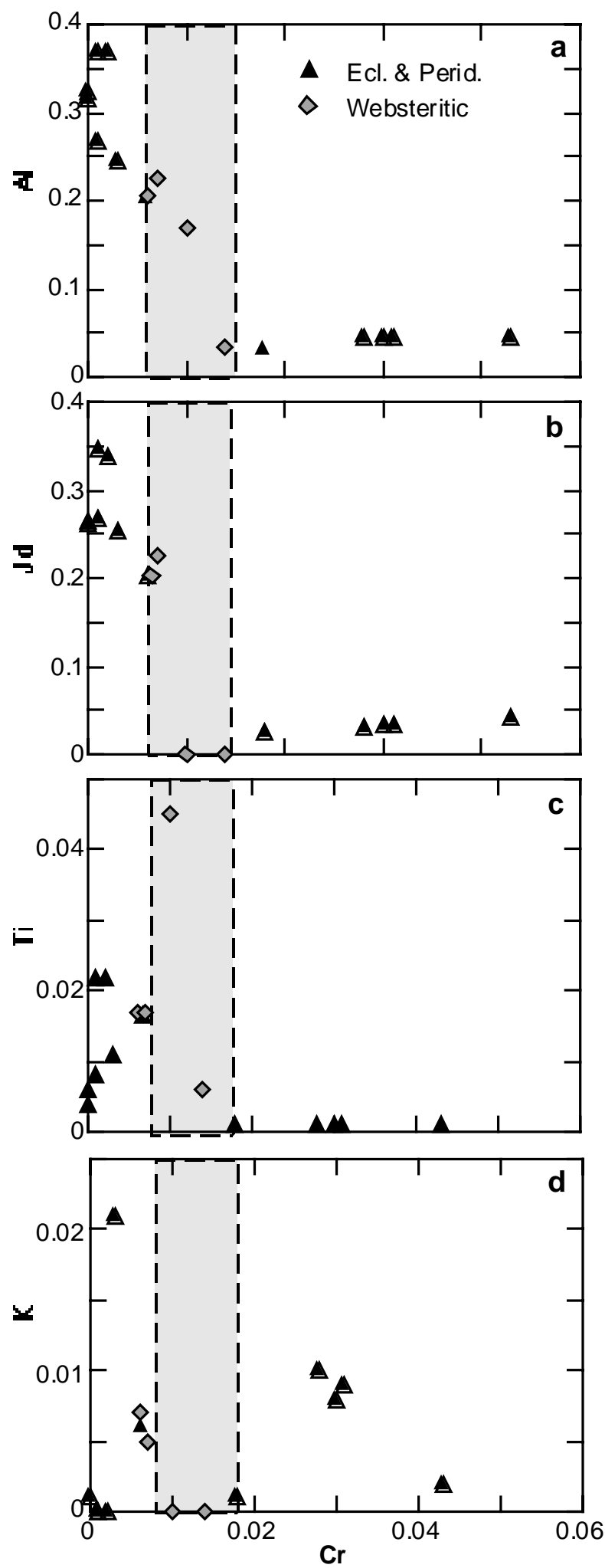

Figure 2. Major element compositions of clinopyroxene inclusions (cations per 6 oxygens) with eclogitic, peridotitic and websteritic (shaded area) compositions.

Temperature estimates for an eclogitic garnet and clinopyroxene inclusion in mutual contact yields a temperature of $1210^{\circ} \mathrm{C}$ at a pressure of $5 \mathrm{GPa}$ (Ellis and
Green, 1979). The temperature calculated for a garnetolivine pair in a lherzolitic diamond at $5 \mathrm{GPa}$ is similar (1255 ${ }^{\circ}$; O’Neill and Wood 1979).

\section{CARBON ISOTOPES}

Carbon isotope values cluster in three zones across a large range $\left(\delta^{13} \mathrm{C}=-21\right.$ to $-2.7 \%$; Fig. 3$)$. Most samples group around a peak with a typical average mantle value $\left(\delta^{13} \mathrm{C}\right.$ av. -5) including diamond containing ferropericlase, peridotitic, eclogitic and eclogitic + websteritic phases.

Eclogitic diamonds have the most ${ }^{13} \mathrm{C}$-depleted values, while diamonds with majorite, eclogitic, peridotitic and websteritic inclusions have intermediate compositions $\left(\delta^{13} \mathrm{C}=-14.7\right.$ to $\left.-11.8 \%\right)$. The ${ }^{13} \mathrm{C}$-depleted values suggest a possible origin from subducted oceanic lithosphere mixed with organic matter.

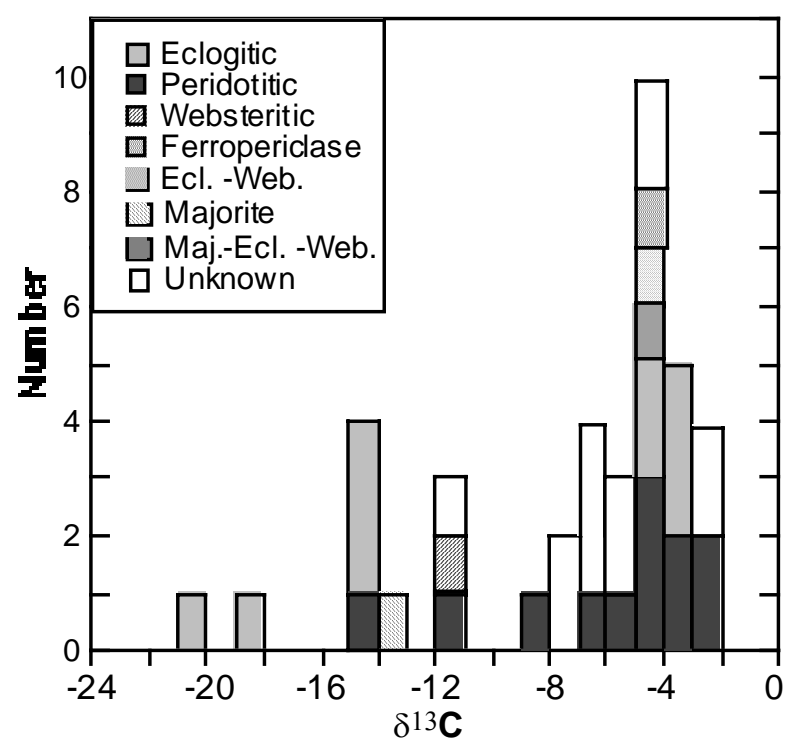

Figure 3. Carbon isotopes versus diamond parageneses in the K10 and K14 diamonds.

\section{NITROGEN CONTENTS AND NITROGEN AGGREGATION STATES}

Two diamond groups are identified from their infrared spectral characteristics: (1) 75\% are nitrogen-free (Type II) or have fully aggregated nitrogen defects (Type IaB) with platelet degradation and moderate nitrogen contents $(<750$ ppm-N); (2) $25 \%$ have low nitrogen aggregation states and moderate to high nitrogen contents $(<30 \% \mathrm{IaB}$; $<1600$ ppm-N). The occurrence of pure IaB defects suggests that the diamonds were affected by storage in the mantle at high temperatures, over a long residence time, and/or significant strain. Strong deformation evident in these diamonds suggests that the high degrees of nitrogen 
aggregation could reflect this process. The Type IaA-IaB diamonds suggest the presence of a younger generation of diamonds that experienced shorter mantle storage histories. Half of these diamonds also show strong deformation features.

All diamond types are represented in the Type II and IaB IR-group (eclogitic, peridotitic with lherzolitic and harzburgitic inclusions, websteritic and diamonds containing ferropericlase and majorite). The Type I diamonds with low nigtrogen aggregation states and average mantle carbon isotope values are peridotitic (Fig. $4)$.

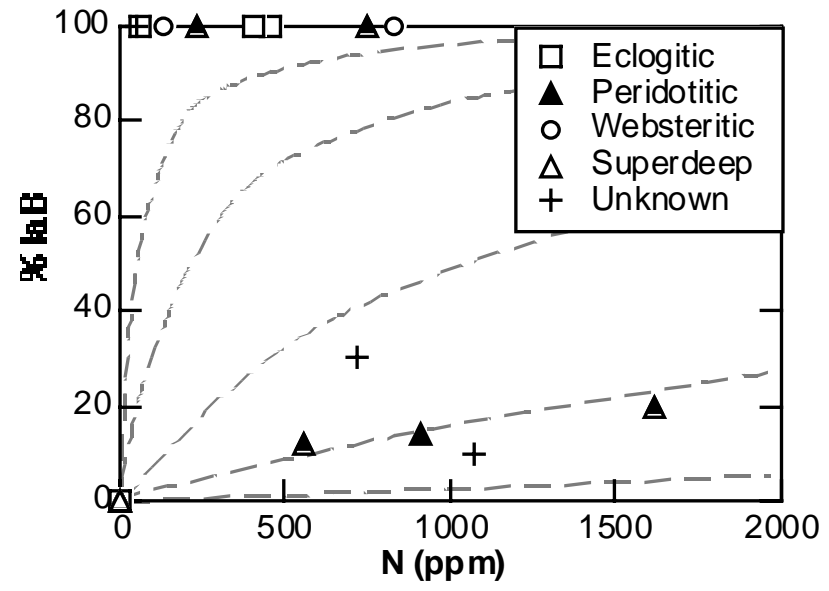

Figure 4. Nitrogen contents versus nitrogen aggregation states and inclusion parageneses in the K10 and K14 diamonds. The dashed isochron lines define areas of similar nitrogen contents and aggregaton states, inferring similar temperature/time/deformation histories.

\section{DISCUSSION}

The combined evidence suggests two generations of diamond growth. Type II diamonds containing ultradeep phases (majorite and ferropericlase) formed in the transition zone and possibly the lower mantle $(\geq 400 \mathrm{~km})$ and were transported to the base of the Alberta lithosphere. Here, diamonds containing peridotitic, websteritic and eclogitic inclusion compositions with Type II and low-N Type IaB character, crystallised or continued to grow from fluids in peridotitic and eclogitic material.

Mechanisms by which diamonds are transported from the transition zone and lower mantle to the lithosphere suggests the involvement of plume transportation. The interaction of partial melts with eclogitic and peridotitic rocks in the plume may have produced the intermediate websteritic inclusion compositions, and can explain diamonds of mixed parageneses and the overlap in carbon isotope values (eg. Wang, 1998). Plume transport at high $\mathrm{T}$ can explain the deformation in the diamonds and the extremely high nitrogen aggregation states. A younger diamond generation, with Type IaA-IaB nitrogen aggregation, later crystallised in peridotitic mantle at the base of the cratonic lithosphere.

A plume model for the Buffalo Hills Craton is congruent with studies of the Slave Craton mantle to the northeast, the two regions being separated by the Great Slave Lake Shear Zone. However, the diamonds from Buffalo Hills and the Central Slave Craton share few commonalities, indicating different mantle histories.

\section{REFERENCES}

Davies, RM, Griffin, WL, O'Reilly, SY, Doyle, BJ (2003): Mineral inclusions and other geochemical characteristics of microdiamonds from kimberlites at Lac de Gras, central Slave craton, Canada; this volume.

Ellis, DJ and Green, DH (1979): An experimental study of the effect of $\mathrm{Ca}$ upon garnet-clinopyroxene $\mathrm{Fe}-\mathrm{Mg}$ exchange equilibria; Contributions to Mineralogy and Petrology, 71: $13-22$

Griffin, WL, Doyle, BJ, Ryan, CG, Pearson, NJ, O'Reilly, SY, Davies, RM, Kivi, K, Van Achterbergh, E and Natapov, LM (1999): Layered mantle lithosphere in the Lac de Gras area, Slave Craton: composition, structure and origin; Journal of Petrology, 40: 705-727.

Irifune, T (1987): An experimental investigation of the pyroxene-garnet transformation in a pyrolite composition and its bearing on the constitution of the mantle; Earth and Planetary Science Letters, 45: 324-336.

Ito, E and Takahashi, E (1989): Postspinel transformations in the system $\mathrm{Mg}_{2} \mathrm{SiO}_{4}-\mathrm{Fe}_{2} \mathrm{SiO}_{4}$ and some geophysical implications; Journal of Geophysical Research, 94: 10637-10646.

O'Neill, HSC and Wood, BJ (1979): An experimental study of Fe-Mg partitioning between garnet and olivine and its calibration as a geothermometer; Contributions to Mineralogy and Petrology, 70: 59-70.

Sobolev, NV, Snyder, GA, Taylor, LA, Keller, RA, Yefimova, ES, Sobolv,VN, Shimizu, N (1998): Extreme chemical diversity in the mantle during eclogitic diamond formation; evidence from 35 garnet and 5 pyroxene inclusions in a single diamond; International Geology Review, 40: 567-578.

Stachel, T, Harris, JW and Brey, GP (1998): Rare and unusual mineral inclusions in diamonds from Mwadui, Tanzania. Contributions to Mineralogy and Petrology, 132: 34-47.

Stachel, T, Harris, JW, Brey, GP and Joswig, W (2000): Kankan dimonds (Guinea) II: lower mantle inclusion paragenesis; Contributions to Mineralogy and Petrology, 140: 16-27.

Wang, W (1998): Formation of diamond with mineral inclusions of "mixed" eclogite and peridotite paragenesis; Earth and Planetary Science Letters, 160: 831-843.

Contact: RM Davies, Department of Earth and Planetary Sciences, American Museum of Natural History, Central Park West at $79^{\text {th }}$ St, New York, NY 10024-5192, USA. Email: rdavies@amnh.org; Tel: 1-212-769 5314; Fax: 1-212-769 5339 